\title{
LAPIS LAZULI FROM THE Coquimbo Region, ChILE
}

\author{
By Robert R. Coenraads and Claudio Canut de Bon
}

Lapis lazuli has been mined from the Coquimbo Region of Chile since 1905. Some of this material approaches the quality of fine lapis lazuli from Afghanistan. The Chilean material is composed of blue lazurite, together with wollastonite, calcite, haüyne, diopside, pyrite, and minor quantities of other minerals. The deposit is located in the Andes Mountains at an elevation of $3,500 \mathrm{~m}$; it is hosted by a contact-metamorphosed limestone that was later metasomatized to introduce sulfur, a necessary component for the formation of lazurite. Two companies are currently mining the deposit, Las Flores de Los Andes S.A. and Compañía Minera LapisChile S.A., and today they produce about 150 tonnes of material annually. Much of the lapis lazuli is processed locally, for use in fine jewelry, ornamental objects, and building materials such as tabletops or tiles.

ABOUT THE AUTHORS

Dr. Coenraads (coenraad@firstnet.com.au) is a consulting geologist, geophysicist, and gemologist, based in Sydney, Australia; a research associate with the Australian Museum in

Sydney; and a lecturer for the Gemmological Association of Australia. Dr. Canut de Bon is a lecturer at the University of La Serena, La

Serena, Quinta Region, Chile.

Please see acknowledgments at the end of the article.

Gems \& Gemology, Vol. 36, No. 1, pp. 28-41

(C) 2000 Gemological Institute of America apis lazuli is a rock composed of lazurite-the source of the blue color-with variable amounts of other minerals depending on its origin and, typically, small particles of pyrite. Prized for its attractive blue color, lapis lazuli was used in jewelry by some of the world's most ancient civilizations. The stone is mined at relatively few locations, some of which have been worked since the fifth millennium BC (von Rosen, 1990).

Considering the extensive history and romance attached to this ornamental gem material, the Chilean deposit is a relative newcomer. The first reference to Chilean lapis lazuli dates back to the 19th century (Field, 1850a and b). Another early mention was made by Ignacio Domeyko (1860), a Polish immigrant and mining engineer who became the first director of the School of Mines at La Serena (about $140 \mathrm{~km}$ from the workings). The first detailed geologic studies of the deposit and mine workings were carried out by German geologist J. Bruggen (1921, 1926), who identified the host rock as contact-metamorphosed limestone. Lapis lazuli was officially recognized as the national gemstone of Chile in 1984.

The Coquimbo Region is the only known source of lapis lazuli in Chile. Although reference is sometimes made to another Chilean deposit at Vicuña Mackenna Mountain near Antofagasta (Webster, 1994; Sofianides and Harlow, 1990), this material has been identified as dumortierite by Canut de Bon (1991). Once considered a minor or unimportant locality, with the lapis lazuli described as "at best mediocre" (Wyart et al., 1981), the Chilean deposit has produced significant quantities of attractive material in recent years. Today, Chilean lapis lazuli is exported in the rough, or incorporated into jewelry (see, e.g., figure 1), carvings, and decorative building materials by local artisans. This article will review the historical significance of lapis lazuli, and examine the geologic setting and gemological characteristics of material from Chile. 
Figure 1. Chilean lapis lazuli is currently used in a variety of ways, but the finer-quality material is incorporated into jewelry. This sterling silver brooch $(3.8 \times 2.5 \mathrm{~cm})$ was manufactured by Chilean artisans. Photo by Maha Tannous.

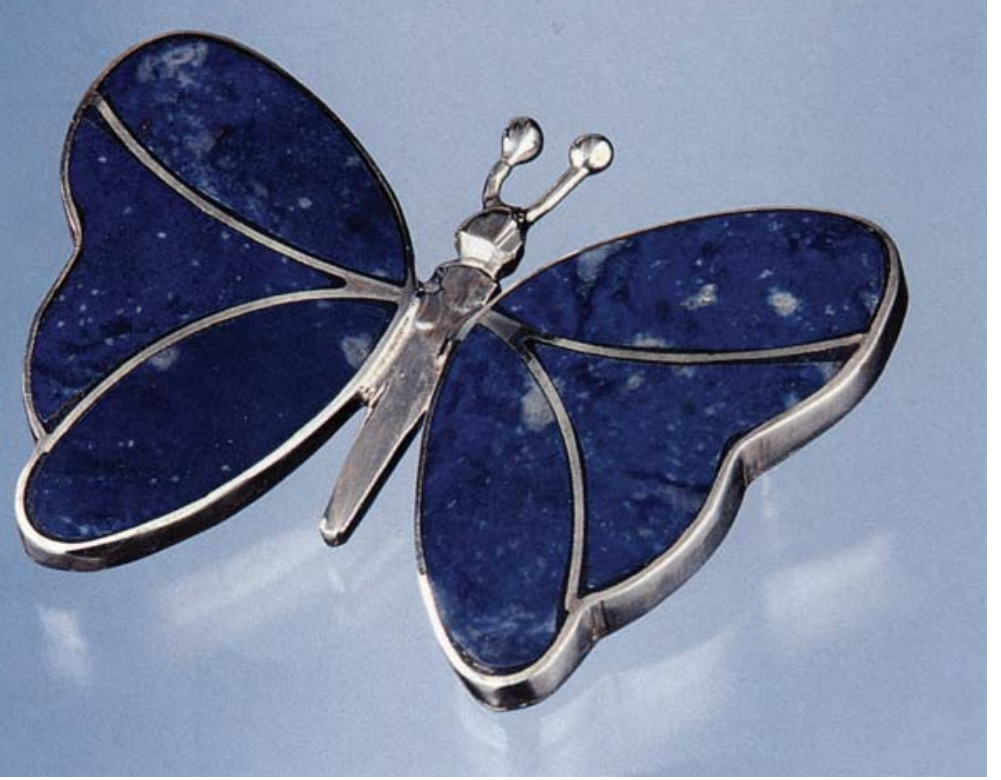

\section{HISTORICAL BACKGROUND}

Lapis lazuli was one of the first gem materials used for adornment and as an ornamental stone in the Middle East, Asia, and Europe. Most of the material used by these ancient civilizations is believed to have originated from the Sar-e-Sang deposit in present-day Badakhshan, Afghanistan (Wyart et al., 1981).

Mesopotamia. The earliest archeological evidence for lapis lazuli's use was traced back to the 5th millennium BC by von Rosen (1990), who recorded the discovery of beads at a cemetery outside the temple walls of Eridu (Sumer) in southern Babylonia (later known as Mesopotamia; now Iraq).

The earliest known written reference to lapis lazuli is found in the Sumerian Poem of Gilgamesh, which was recovered on 12 engraved clay tablets from the ruins of the palace library of the Assyrian King Ashurbanipal in Nineveh (near present-day Al Mawsil in northern Iraq; Heidel, 1946). The hero, Gilgamesh, was a king in southern Mesopotamia who actually lived sometime between 2700 and 2500 BC (Tiglay, 1982). In the epic, the goddess of love offers to be the wife of Gilgamesh, and promises "a chariot of lapis lazuli and gold." Artistic works containing lapis lazuli from this period were recovered in the 1920s, during excavations of the ancient Chaldean city of Ur (near present-day An Nasiriyah in southern Iraq). The most famous of these were recovered from the royal tomb of Queen Pu-abi (2500 BC), including three gold headdresses and two bead necklaces (Sofianides and Harlow, 1990; Sutherland, 1991), as well as two statues of male goats with fleece, shoulders, eyes, and horns of lapis lazuli (see, e.g., figure 2).
Egypt. Lapis lazuli was used for scarabs, pendants, beads, and inlaid jewelry in Egypt prior to 3100 BC (Sofianides and Harlow, 1990). The tombs of Ramses II (circa $1279 \mathrm{BC}$ ) and Tutankhamun (1361-1352 BC) revealed rings and other jewelry made of lapis lazuli. In fact, the golden mask over the head and shoulders of Tutankhamun's mummy has eyebrows and areas around the eyes that are inlaid with lapis lazuli (Silverman, 1978).

China. The use of lapis lazuli was mentioned in Chinese annals of the sixth and eighth centuries $\mathrm{BC}$, as the stone was a favorite with Chinese carvers (Bowersox and Chamberlin, 1995). Some Chinese hair and belt ornaments carved from lapis lazuli have been dated to 551-479 BC (Sofianides and Harlow, 1990).

Europe. Curiously, most modern Bibles use the term sapphire to denote lapis lazuli (Douglas, 1980). This is because sappir and sappheiras were used in the early Old Testament Massoretic and Septuagint texts, respectively (Douglas, 1980). It is generally recognized that true sapphire was scarcely known to the ancients, and that the "sapphire" of antiquity was in fact lapis lazuli that contained golden specks of pyrite (Burnham, 1886). The term lapis lazuli came into use in the Middle Ages and derives from the ancient Persian lazhuward (blue) and Arabic lazaward (heaven, sky, or blue; Sofianides and Harlow, 1990). Historically, lapis lazuli was crushed for use as a blue pigment, "ultramarine," until 1826 when an inexpensive substitute was developed by J. B. Guimet (Wyart et al., 1981). 


\section{LAPIS LAZULI IN THE AMERICAS}

Three lapis lazuli deposits are known in North America (Sinkankas, 1997): Italian Mountain in Colorado (Christopher, 1977; Hogarth and Griffin 1980; Schultz, 1981), the San Gabriel Mountains in California (Rogers, 1938), and Baffin Island in Canada (Hogarth and Griffin, 1978). These have been mined sporadically during this century, primarily for local ornamental use, although some blocks of "azure-blue material" from Italian Mountain have been sent to Idar-Oberstein, Germany, for carving (Sinkankas, 1997).

In South America, there have been several recent references to the use of lapis lazuli by the Moche (800-100 BC) and Inca (1100-1537 AD) cultures, which occupied present-day Peru, Ecuador, Bolivia, northern Chile, and northwestern Argentina (e.g., Sofianides and Harlow, 1990). However, the accuracy of these identifications has been questioned by one of the authors (Canut de Bon, 1991), who has not confirmed any archeological evidence of the

Figure 2. Several artistic works were recovered in the 1920s during excavations of the Chaldean city of Ur (in southern Iraq). This statue of a goat (42.6 cm tall), called "Ram Caught in a

Thicket," dates back to the mid-3rd millennium $B C$ and is made of gold, silver, ornamental stone, and lapis lazuli and shell that are set in bitumen. Photo courtesy of the University of Pennsylvania Museum (\#T4-1000).

During the Renaissance, lapis lazuli was used for cups, bowls, and urns, and was inlaid into clock faces and tables. The popular flower, bird, and butterfly mosaics of Florence used lapis lazuli, along with carnelian, malachite, and agate, skillfully set into a background of black Belgian marble (Hinks, 1975). In Renaissance Russia, lapis lazuli was used as a decorative stone, as at the Winter Palace in St. Petersburg and the Palace of Catherine the Great in TsarskoeSelo (now the city of Pushkin; Bauer, 1904).

More recently, at the turn of the 20th century, French jeweler and artist Peter Carl Fabergé (1846-1920) used lapis lazuli in many of his major works. Among these was one of his 58 Imperial Easter Eggs_a gift from Czar Nicholas II of Russia to Czarina Alexandra in 1912 (figure 3).

Figure 3. Intricate gold work is combined with lapis lazuli in this "Imperial Czarevitch Easter Egg" $(12.5 \times 8.9 \mathrm{~cm})$, made in 1912 by Peter Carl Fabergé. Courtesy of the Virginia Museum of Fine Arts, Richmond. Bequest of Lillian Thomas Pratt. Photo: Katherine Wetzel. (C) Virginia Museum of Fine Arts.

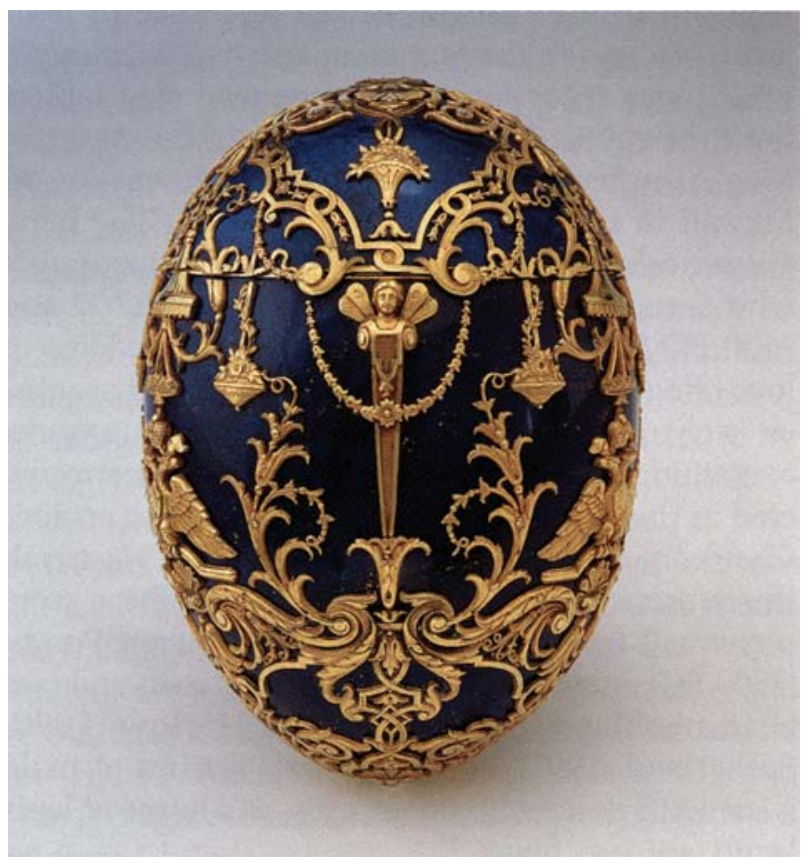




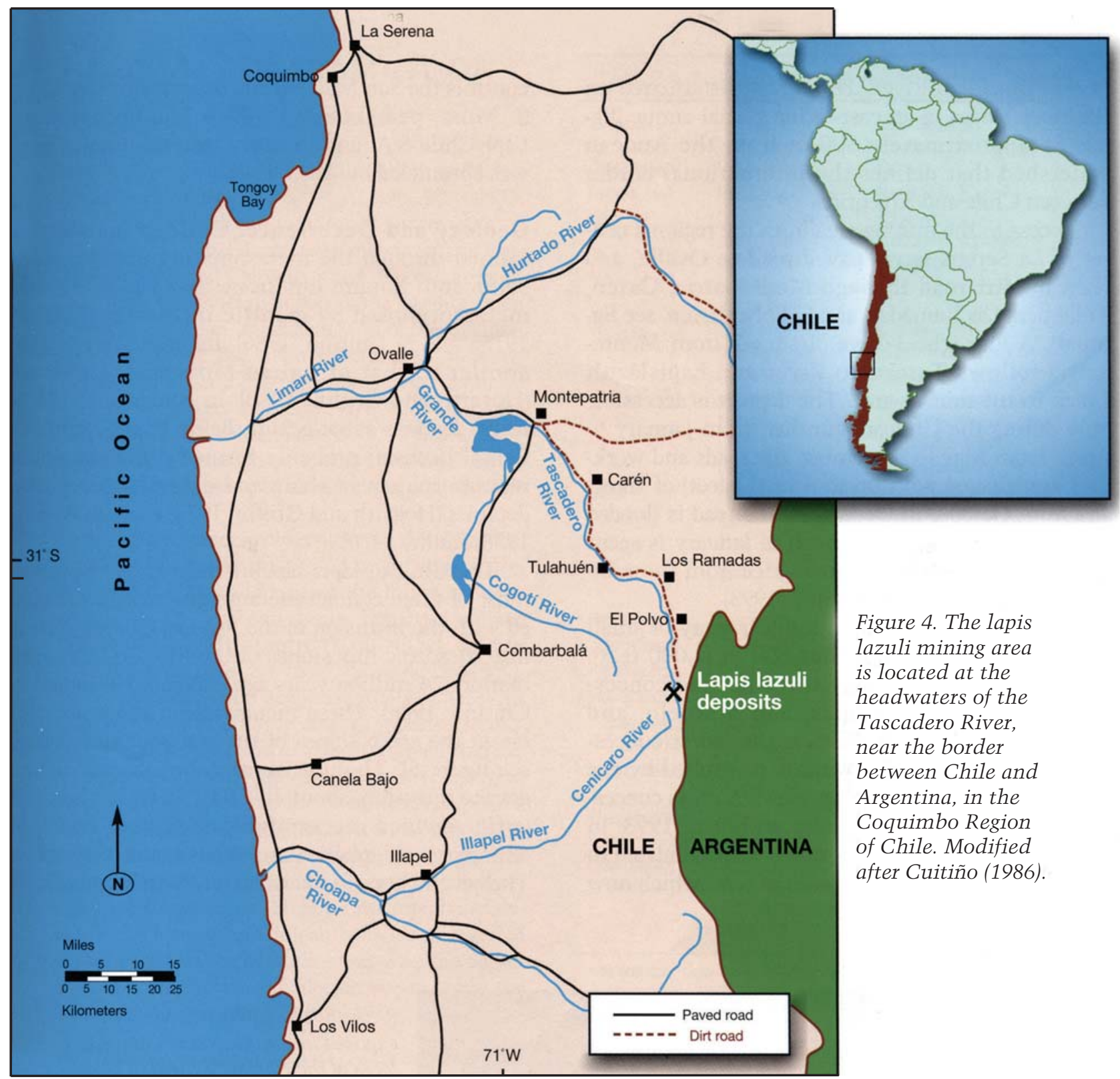

early use of lapis lazuli from Chile. In fact, preColumbian artifacts from both national and foreign museums that were studied at the University of La Serena have been found to contain sodalite or other blue minerals, but not lapis lazuli (Canut de Bon, 1991). The Moche use of sodalite is consistent with the observation that the peoples of the Bolivian and Peruvian altiplano commonly used this mineral for beads and carvings (Brendler, 1934). However, evidence of human activity near the lapis lazuli mining area-including flint arrowheads in an old campsite just $300 \mathrm{~m}$ from the mine, and pre-Columbian ceramic fragments near Punta Negra, about $5 \mathrm{~km}$ away-does suggest that the deposit could have been known to early inhabitants of the region $/ \mathrm{S}$. Rivano, pers. comm., 2000; see also Rivano, 1975a and b; Rivano and Sepúlveda, 1991). Further research is needed to determine conclusively if the Coquimbo lapis lazuli deposit was indeed worked by ancient cultures before its modern discovery in the mid-19th century.

\section{THE CHILEAN DEPOSIT}

Location and Access. The mining area lies in the Andes Mountains at an altitude of 3,500 m (11,480 feet). Geographically, it is located southeast of Montepatria, in Chile's Coquimbo Region (figure 4), at the headwaters of Lapislázuli Creek, a tributary 
of the Tascadero River. The deposit is situated on the steep slopes of an east-facing glacial cirque (figure 5), approximately $500 \mathrm{~m}$ from the Andean watershed that defines the international border between Chile and Argentina.

Access to the mining area from the regional center of La Serena is via paved road to Ovalle, and then by dirt road through Montepatria, Carén, Tulahuén, Las Ramadas, and El Polvo (again, see figure 4). A four-wheel-drive dirt track from Montepatria follows Tascadero River and Lapislázuli Creek to the mining area. The deposit is accessible only during the Chilean summer, from January to April. From May to September, the roads and workings are covered with up to $4 \mathrm{~m}$ (13 feet) of snow; and from October to December, the road is flooded by melt water. Typically much of January is spent repairing the road and removing ice from the mining pits (R. Vega E., pers. comm., 1993).

The deposit is mined in a linear array of small pits over a distance of about $600 \mathrm{~m}$ (2,000 feet). These pits are covered by three mining concessions-Flor de Los Andes, San Marcelo, and Seguridad. Flor de Los Andes is the oldest concession, established in 1952, and is controlled by the company Las Flores de Los Andes S.A.; this concession was visited by the senior author in 1993. In 1995, a group of Chilean companies consolidated to form Compañía Minera LapisChile S.A., which now controls the San Marcelo and Seguridad concessions (J. Muxi, pers. comm., 1999). The formation of LapisChile S.A. and its entry into the marketplace was chronicled by Ward (1996).

Geology and Occurrence. Chilean lapis lazuli formed through the metasomatic introduction of sulfur into impure limestone that was previously metamorphosed by granitic intrusives (Rivano, $1975 \mathrm{a}$ and b; Cuitiño, 1986). Its origin is probably similar to that of Italian Mountain, Colorado (Hogarth and Griffin, 1980). In contrast, the lapis lazuli deposits at Sar-e-Sang, Baffin Island, and Lake Baikal (Russia) probably formed during regional metamorphism of shale and dolomitic evaporite deposits (Hogarth and Griffin, 1978; see also Ivanov, 1976; Kulke, 1976).

The Chilean lapis lazuli is hosted by the outermost of three contact-metamorphic zones associated with the intrusion of the Río Las Cuevas granite into Mesozoic limestones of the Río Tascadero formation, 24 million years ago (Rivano, 1975a and b; Cuitiño, 1986). These metamorphic zones are visible in the steep slopes of the glacial cirque (again, see figure 5). The innermost zone adjacent to the granite intrusion, about $40-50 \mathrm{~m}$ wide, is a hornfels (a fine-grained metamorphic rock) that contains clinopyroxene, plagioclase, quartz, and magnetite. The second zone, a skarn about $80-100 \mathrm{~m}$ wide, is

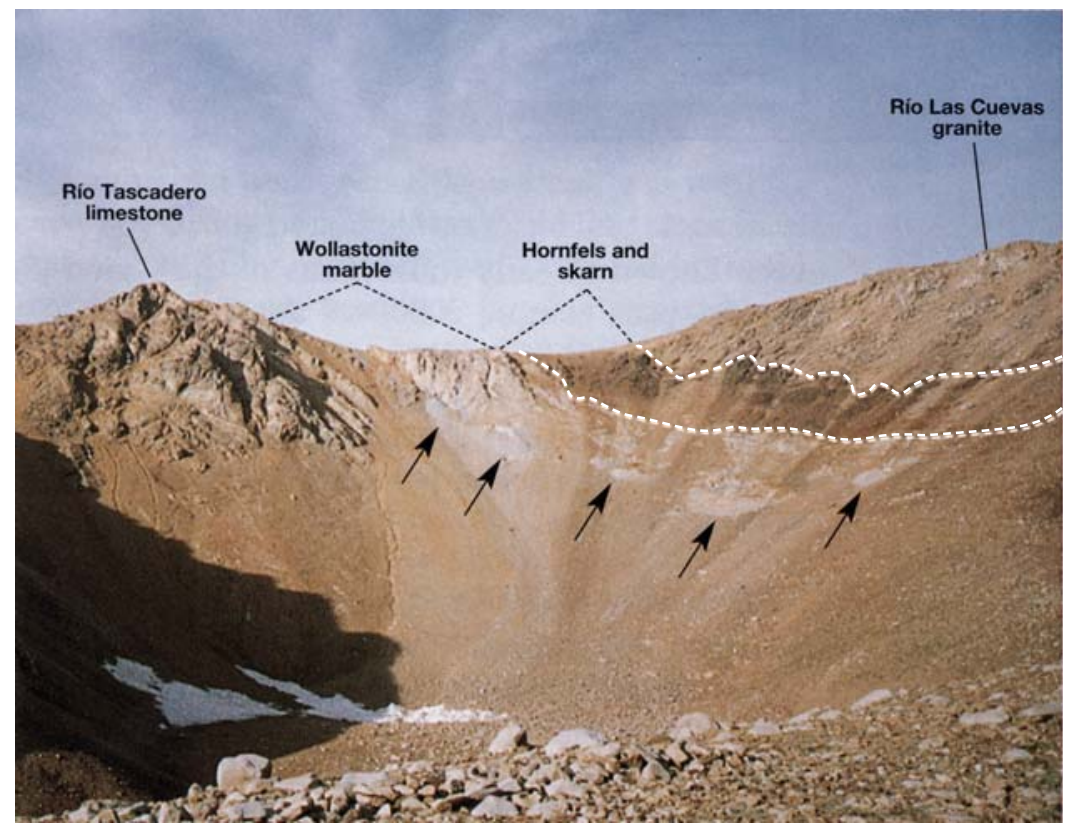

Figure 5. The geology is well exposed in the steep north and east faces of the glacial cirque that hosts the lapis lazuli deposits. Two of the three contact-metamorphic zones adjacent to the granite are distinguishable. The innermost hornfels zone and the second skarn zone form a dark band, with an irregular contact against the gray-colored granite. The outer zone is a "cream"-colored wollastonite marble displaying a sharp, straight contact with the second zone. The marble hosts local lenses of lapis lazuli exposed by a linear array of mining cuts with blue-tinged dumps (arrows), barely visible near the top of the scree slopes. The contact between the outermost marble zone and the limestone is obscured by scree. 


\section{BOX A: Mineralogy OF LAPIS LAZULI}

Lazurite is a member of the sodalite group, which has the general formula: $\mathrm{Na}_{6}(\mathrm{Na}, \mathrm{Ca})_{2}\left(\mathrm{Al}_{6} \mathrm{Si}_{6} \mathrm{O}_{24}\right) \mathrm{X}_{1-2} \cdot \mathrm{nH}_{2} \mathrm{O}$, where $\mathrm{X}=\mathrm{Cl}, \mathrm{OH}, \mathrm{SO}_{4}$, and/or $\mathrm{S}$, and $\mathrm{n}=0$ or 1 (Gaines et al., 1997). Lazurite is anhydrous and contains both $\mathrm{Na}$ and $\mathrm{Ca}$, with $\mathrm{S}$ and $\mathrm{SO}_{4}$ occurring in the $\mathrm{X}$ site. The other members of the sodalite group are sodalite, nosean, and haüyne. All of these minerals crystallize in the cubic system, and can show blue color; lazurite has commonly been confused with sodalite (see, e.g., table A-1). However, the "bright azure" or "ultramarine blue" of fine lazurite is somewhat distinctive, and is the most highly prized color attained by minerals of the sodalite group.

Using microscopic observation of thin sections, as well as X-ray diffraction and microprobe analyses, Cuitiño (1986) identified the following constituents in Chilean lapis lazuli: lazurite $(39 \%-66 \%)$, wollastonite $(20 \%-43 \%)$, calcite $(1 \%-21 \%)$, haüyne $(2 \%-6 \%)$, diopside $(2 \%-5 \%)$, pyrite $(1 \%-4 \%)$, and scapolite $(0.3 \%-4 \%)$, with traces $(<1 \%)$ of siderite, epidote, plagioclase, tremolite, sodalite, afghanite, allanite, arsenopyrite, pyrrhotite, and chalcopyrite. It is interesting to compare these with the list of minerals identified in lapis lazuli from Afghanistan by Wyart et al. (1981): lazurite, calcite, and dolomite, associated with forsterite, plagioclase, diopside, scapolite, phlogopite, and pyrite. Electron microprobe analyses of the lazurite in Chilean lapis lazuli revealed that the greater the sulfur content was, the darker the blue color appeared; chlorine was noted in the greenish blue varieties (Cuitiño, 1986).
TABLE A-1. Properties of lazurite and sodalite ${ }^{a}$.

\begin{tabular}{|c|c|c|}
\hline Property & Lazurite & Sodalite \\
\hline Crystal system & Cubic & Cubic \\
\hline Formula & $\mathrm{Na}_{6} \mathrm{Ca}_{2}\left(\mathrm{Al}_{6} \mathrm{Si}_{6} \mathrm{O}_{24}\right) \mathrm{S}_{2}$ & $\mathrm{Na}_{8}\left(\mathrm{Al}_{6} \mathrm{Si}_{6} \mathrm{O}_{24}\right) \mathrm{Cl}_{2}$ \\
\hline Habit & $\begin{array}{l}\text { Dodecahedra or cubo- } \\
\text { octahedra up to } 5 \mathrm{~cm} \text {; } \\
\text { more commonly com- } \\
\text { pact, massive; often } \\
\text { with pyrite and calcite }\end{array}$ & $\begin{array}{l}\text { Dodecahedra, cubo- } \\
\text { dodecahedra, octahedra; } \\
\text { usually massive }\end{array}$ \\
\hline Twinning & $\begin{array}{l}\text { Common on }\{111\} \text {, but } \\
\text { generally not apparent }\end{array}$ & $\begin{array}{l}\text { Common on }\{111\} \text {, forming } \\
\text { pseudo-hexagonal prisms }\end{array}$ \\
\hline Color & $\begin{array}{l}\text { Blue, white, gray, } \\
\text { yellow, greenish } \\
\text { blue, colorless }\end{array}$ & $\begin{array}{l}\text { Colorless, gray, white, } \\
\text { greenish or yellowish } \\
\text { white, light to medium } \\
\text { blue, violet blue, pink }\end{array}$ \\
\hline Luster & Dull to vitreous & Vitreous to greasy \\
\hline Streak & Bright blue & White or very pale blue \\
\hline Diaphaneity & Translucent to opaque & Transparent to translucent \\
\hline Cleavage & $\{110\}$ distinct & $\{110\}$ poor to distinct \\
\hline Fracture & Uneven, brittle & $\begin{array}{l}\text { Uneven to conchoidal, } \\
\text { brittle }\end{array}$ \\
\hline Hardness & $5-5.5$ & $5.5-6$ \\
\hline Specific gravity & $2.38-2.45$ & $2.14-2.30$ \\
\hline Refractive index & $1.500-1.522$ & $1.483-1.487$ \\
\hline \multicolumn{3}{|l|}{ Fluorescence } \\
\hline Short-wave UV & None & $\begin{array}{l}\text { Intense orange to } \\
\text { orange-red }\end{array}$ \\
\hline Long-wave UV & None & $\begin{array}{l}\text { Intense orange to } \\
\text { orange-red }\end{array}$ \\
\hline Phosphorescence & None & $\begin{array}{l}\text { Often short-lived } \\
\text { yellowish white }\end{array}$ \\
\hline $\begin{array}{l}\text { Distinguishing } \\
\text { features }\end{array}$ & $\begin{array}{l}\text { Bright blue streak; } \mathrm{H}_{2} \mathrm{~S} \\
\text { (rotten egg smell } \\
\text { liberated upon applica- } \\
\text { tion of } \mathrm{HCl} \text { ) }\end{array}$ & $\begin{array}{l}\text { Absence of pyrite (except } \\
\text { rare cases), almost white } \\
\text { streak }\end{array}$ \\
\hline
\end{tabular}

aReferences: Deer et al., 1963; Schumann, 1997;

Anthony et al., 1995; Webster, 1994; Gaines et al., 1997.

of hydrothermal alteration associated with the Portezuelo del Azufre intrusion, which is exposed 3 $\mathrm{km}$ south of the lapis lazuli workings, and was emplaced about 10-11 million years ago (Rivano and Sepúlveda, 1991). This superposition of two unrelated geologic events explains the uniqueness of this lapis lazuli deposit in the Andean Cordillera of South America.

Mining. The irregular lenses of lapis lazuli are mined in small cuts or quarries (see, e.g., figure 6). Prior to 1996, explosives were used at all three concessions; however, the artisans reported that the lapis lazuli tended to fail along fractures and blamed the use of explosives in the extraction process (W. Vega A., pers. comm., 1993). Las Flores de Los Andes now 


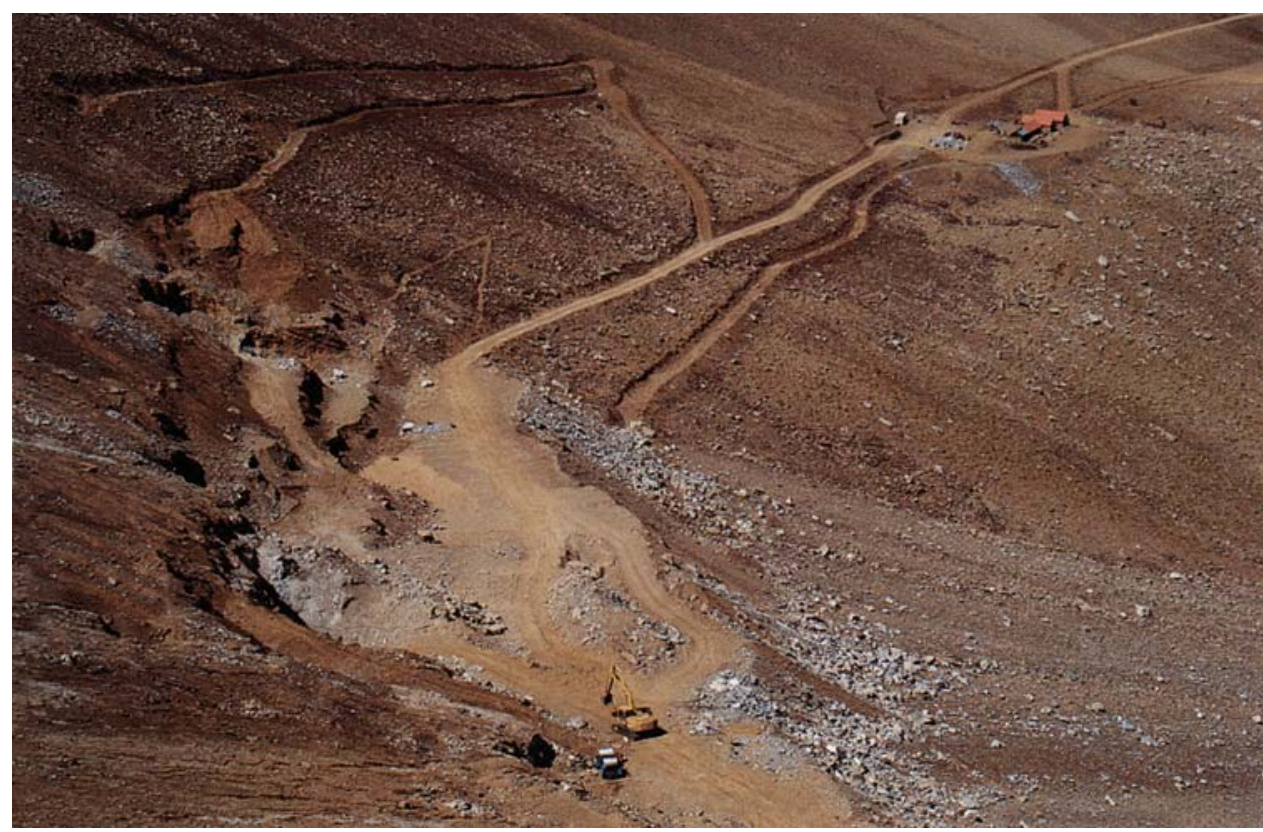

Figure 6. This view of the Flor de los Andes concession shows a series of small cuts that have been explored and mined for lapis lazuli. Photo (C) 2000 Fred Ward.

uses only a limited amount of explosives to break away large blocks of lapis lazuli along lines of closely spaced drill holes (J. Correa, pers. comm., 2000). Some of the blocks recovered are more than $2 \mathrm{~m}$ across. In 1996, granite, marble, and jade quarrying techniques were introduced by LapisChile using expertise from the Canadian nephrite mines (Ward, 1996). LapisChile does not use explosives, but rather diamond-impregnated cable saws in conjunction with drill holes and wedges (J. Muxi, pers. comm., 1999). Las Flores de Los Andes currently employs 20 workers, and LapisChile about 10 workers, in the mining and processing of the material (J. Correa, pers. comm., 2000; B. Lepe, pers. comm., 1999). The ore is hand sorted on site before being transported by truck to Santiago, where it undergoes further processing (figure 7).

Production. Between 1905 and 1910, about 10 tonnes of lapis lazuli from the Coquimbo Region were sent to Germany (Canut de Bon, 1991). Later, small, hand-selected pieces of high-quality lapis lazuli were mined (Zeballos, 1973), and used to supply the local market. Transport at that time was only possible by mule; the journey from the mine to La Serena took two days, and each mule carried 100 kg. Until 1989, when the company constructed an access road navigable by truck, only about 20-30 tonnes of lapis lazuli were being removed annually from Flor de Los Andes (S. Rivano, pers. comm., 2000). Current production is about 150 tonnes a year of mixed-grade material. Of this amount, Las
Flores de Los Andes currently mines about 100 tonnes (J. Correa, pers. comm., 2000), and LapisChile produces about 50 tonnes.

Because the full extent at depth of the lapis lazuli lenses has not been determined-and about $50 \%$ of the surface of the ore zone is covered by scree (landslide debris) - it is difficult to determine how much remains. Canut de Bon (1991) discovered traces of lapis lazuli $5.5 \mathrm{~km}$ north of the present workings and $2 \mathrm{~km}$ to the south in the same geologic formation. Drilling in 1993 at the Flor de Los Andes concession outlined more than 10,000 tonnes of proven reserves and 60,000 tonnes of probable reserves; more recent work indicates even greater reserves at the LapisChile concessions (S. Rivano, pers. comm., 2000).

\section{PROCESSING AND EVALUATION}

Quality Considerations. The term lapis lazuli has been applied to a broad range of material, from pure lazurite to pieces of gray marble that contain less than $30 \%$ lazurite. For the purpose of comparing parameters in a simple grading system, we define lapis lazuli as an ornamental stone that contains varying quantities of lazurite (blue), wollastonite (white), calcite (white to gray), specks of pyrite ("golden" yellow), and minor quantities of other minerals. The key factors in evaluating the quality of lapis lazuli are the percentage and color of the lazurite, as well as the combination and distribution of the colors of the associated minerals.

Since the blue color of lapis lazuli is due to 
lazurite, the maximum amount of this mineral is desirable. In the rare case that a specimen is composed of an aggregate of pure lazurite, it is still called lapis lazuli (rather than lazurite), in the same way that a metamorphic rock consisting of an aggregate of pure calcite is still termed a marble.

The most desirable color of lazurite is a bright, saturated blue "of extraordinary depth and intensity" (Webster, 1994, p. 263), to which the terms ultramarine blue and azure blue have been applied (Arem, 1987; Anthony et al., 1995). The lighter blues, dull dark blues, and green-blues are less desirable.

The mixtures of colors from the main minerals present also influence the quality of lapis lazuli. White and dark blue make a pleasing combination, as does the presence of tiny specks of golden pyrite, whereas a gray and blue combination is far less desirable. The colors should be distributed evenly, and large areas of color other than blue are not desirable. Patchy color variation, veining, and mineral aggregations may be used to good effect by skilled artisans, although such material is generally considered difficult to work. Evenly distributed, finegrained pyrite is desirable, whereas sizable aggregates of pyrite devalue the material.

Grading. Using the factors described above, one of the authors developed a four-category scheme for quality grading Chilean lapis lazuli (Canut de Bon, 1991) that is currently used by Las Flores de Los Andes. First-quality material (figure 8) consists predominantly of dark blue to "ultramarine" blue lazurite, with no gray calcite; small white spots and finely dispersed pyrite may be present. Second-quality lapis lazuli (figure 9, left) is composed predominantly of dark blue to medium blue lazurite, along with significant amounts of white spots and fine specks of pyrite, and minor gray calcite. Third-quality material (figure 9, center) is composed of deep blue to pale blue lazurite, together with appreciable amounts of gray and white minerals and local aggregates of pyrite (or other trace minerals). Fourthquality lapis lazuli (figure 9, right) contains subordinate amounts of lazurite in various tones of blue, with most of the remainder being gray calcite.

LapisChile uses different categories for their products; these categories are based predominantly on the percentage of lazurite present in the piece. They have found that most carvers and jewelry manufacturers will not use pieces of lapis layuli with less than $70 \%$ lazurite, although $50 \%-70 \%$ lazurite is acceptable for carving in

Figure 8. Portions of these brightly colored pieces of lapis lazuli from the San Marcelo claim would be considered "first-quality" according to the grading system used by Las Flores de Los Andes. Note the intense blue color and general lack of impurities in these areas. Photo $@ 2000$ Fred Ward.

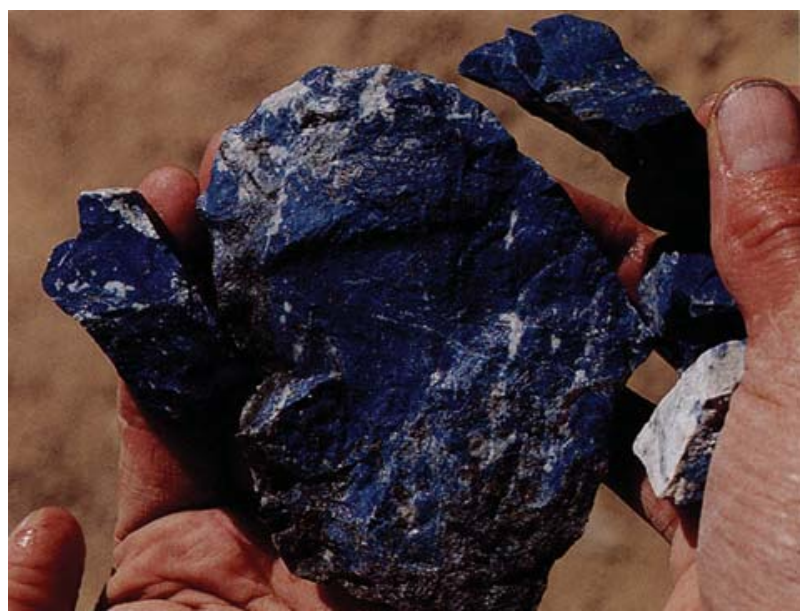



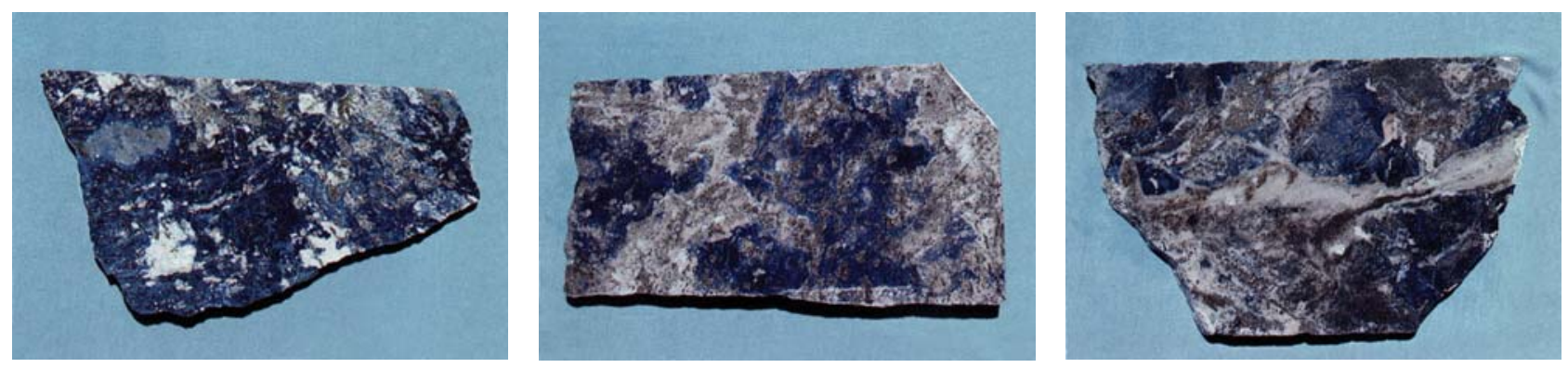

Figure 9. These slabs constitute some of the samples obtained for this study, and illustrate three of the quality grades of lapis lazuli used by Las Flores de Los Andes (see text for discussion); left-second quality (19 $\times$ $11 \mathrm{~cm})$, center-third quality $(18 \times 9 \mathrm{~cm})$, and right-fourth quality $(21 \times 13 \mathrm{~cm})$.

some markets. Material with less than 50\% lazurite is used only for construction materials, such as slabs, countertops, or tiles (J. Muxi, pers. comm., 1999).

Figure 10. This Chilean artisan is forming a sphere of lapis lazuli at his home in La Serena. The spheremaking machinery uses an old diamond-coring bit (inset); the sphere weighs $1.5 \mathrm{~kg}$.

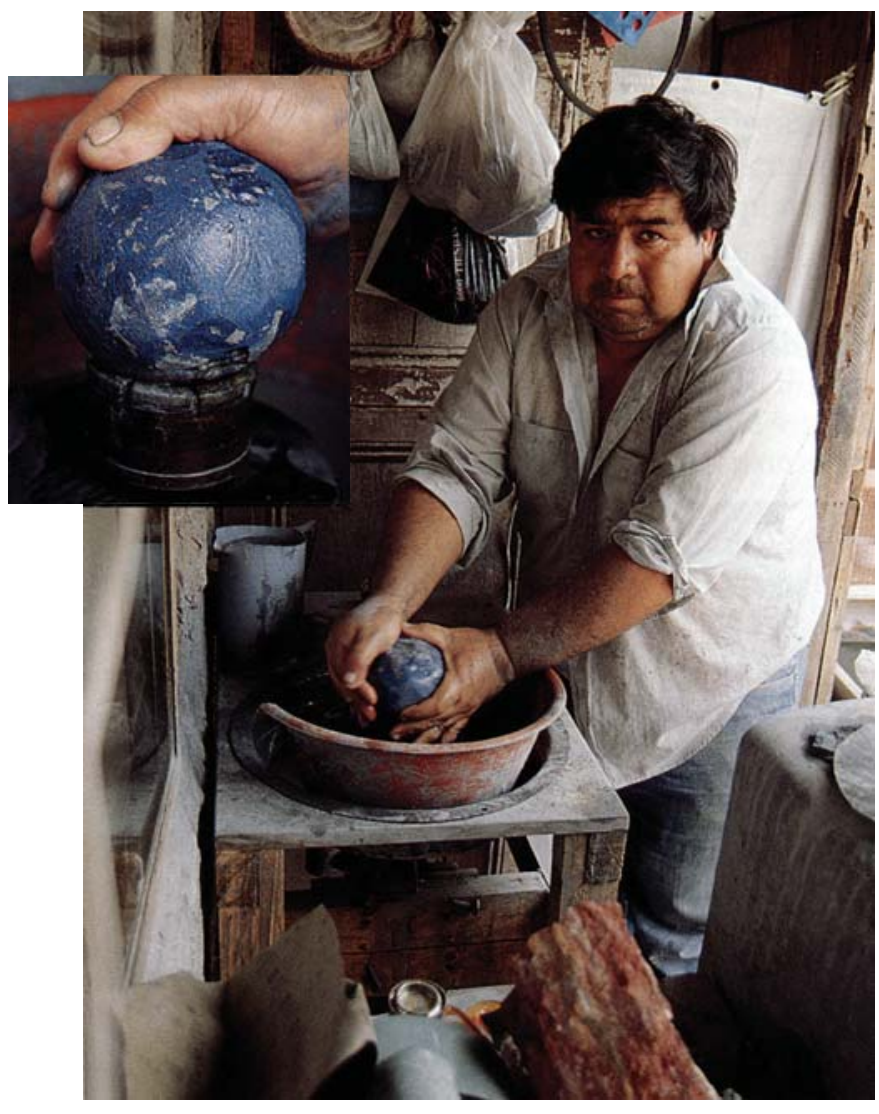

\section{MARKETING AND DISTRIBUTION}

Both LapisChile and Las Flores de Los Andes supply lapis lazuli to the wholesale and retail markets, and also sell processed products-including jewelry, doorknobs, pens, glasses, clocks, spheres, carvings, tabletops, and tiles (see, e.g., LapisChile's Web site, www.cepri.cl/lapislaz/company.html). Most of the lapis lazuli mined by Las Flores de Los Andes is sold as rough material, by the kilogram, in a range of sizes. The majority is processed domestically, with the remainder going primarily to Germany, Italy, and the U.S.

A thriving industry of local Chilean artisans work individually, or in small family groups, to manufacture jewelry and other ornamental objects (figure 10). During a 1993 visit to Chile by the senior author, "Keop's" in Ovalle was one of the largest local buyers; they purchased several thousand kilograms of material annually from Las Flores de Los Andes. The principal artisan, Wellington Vega A., created carvings using fine electric saws and drills, while his employees used the off-cuts to produce cabochons and tumbled pieces. The carvings frequently show interesting patterns created by the spots and veins of associated minerals (figure 11).

Before trucks could access the mining area starting in 1989, lower-quality lapis lazuli was rarely mined. Now that the material can be extracted in larger blocks, today it is being exploited profitably by both LapisChile and Las Flores de Los Andes. Much of this is cut into slabs for use as building products (J. Muxi, pers. comm., 1999). In 1998, Lapis Pigment S.A., a subsidiary of Las Flores de Los Andes, began producing the natural blue pigment "ultramarine" using Chilean lapis lazuli (J. Correa, pers. comm., 2000). 


\section{GEMOLOGICAL TESTING}

Materials and Methods. Lapis lazuli samples representing all four qualities (and rejects) were obtained from the Las Flores de Los Andes processing warehouse in La Serena, and examined at the Australian Museum and Gemmological Association of Australia laboratories in Sydney. The samples consisted

Figure 11. This 17-cm-high figurine of a man smoking a pipe is fashioned from third-quality lapis lazuli. Note how the light-colored areas of the rock are effectively used to highlight portions of the man's clothing and the bowl of his pipe. Oriental themes in carved Chilean lapis lazuli are popular, with finished works being sent to Japan, as well as Italy, France, and Germany.

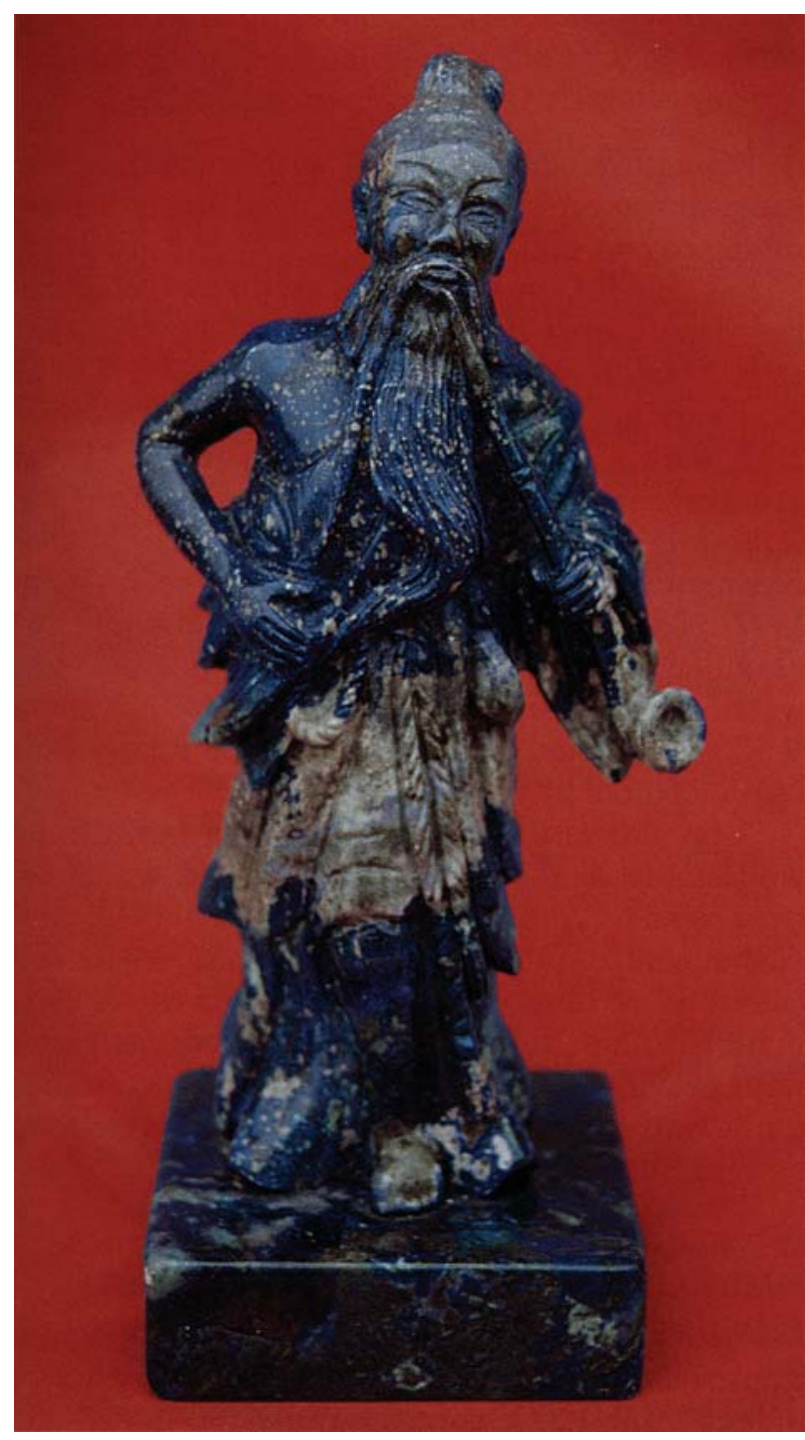

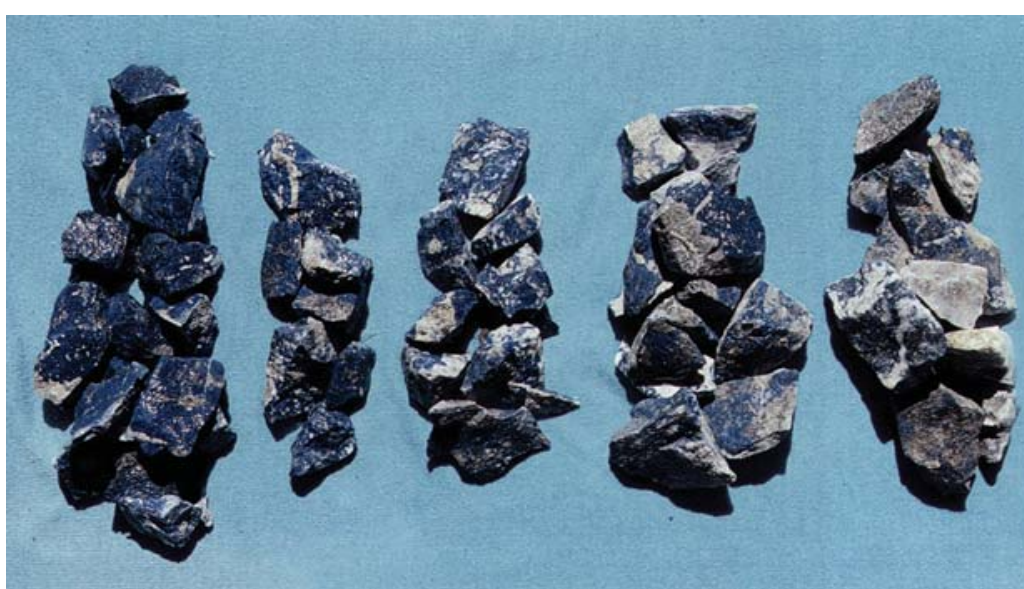

Figure 12. These samples represent the graded material studied by the authors. From left to right: first-quality (150 g), second-quality (100 g), third-quality (100 g), fourth-quality (170 g), and reject material (180 g).

of $700 \mathrm{~g}$ of graded rough (figure 12), five polished slabs totaling $1.8 \mathrm{~kg}$ (see, e.g., figure 9), four free-form cabochons, and a $1.5 \mathrm{~kg}$ sphere (figure 10). The Chilean material was compared with four samples of Afghan lapis lazuli from the Australian Museum's collection: a $150 \mathrm{~g}$ piece of rough and a $14.38 \mathrm{ct}$ cabochon (both "first-quality"), and two specimens with dodecahedral lazurite crystals in a matrix of white calcite and pyrite. Cabochons fashioned from sodalite $(17.14 \mathrm{ct})$ and the following lapis lazuli imitations (loaned from the GIA collection) were also studied: barium sulfate $(4.18 \mathrm{ct}$ ), Gilson-created (2.63 ct), and plastic (1.82 and $5.09 \mathrm{ct}$ ).

All samples were examined with a $45 \times$ binocular microscope, and viewed in a darkened room with a Raytech short- and long-wave ultraviolet lamp. The colors of the different samples were referenced to a Munsell Color Chart and described using the three independent parameters: hue, tone (cf., lightness or darkness value), and saturation (cf., chroma). We used a Topcon refractometer to obtain spot refractive index readings on the Chilean cabochons, and an Oertling R42 hydrostatic balance to determine the specific gravity of most of the samples. Small pieces of first-quality lapis lazuli from Chile and Afghanistan were crushed for powder X-ray diffraction (XRD) analysis at the Australian Museum, and the results were compared to reference diffraction patterns by Diffraction Technology, Australia.

Characteristics of Chilean Lapis Lazuli. Overall, the Chilean lapis lazuli samples varied from light blue 

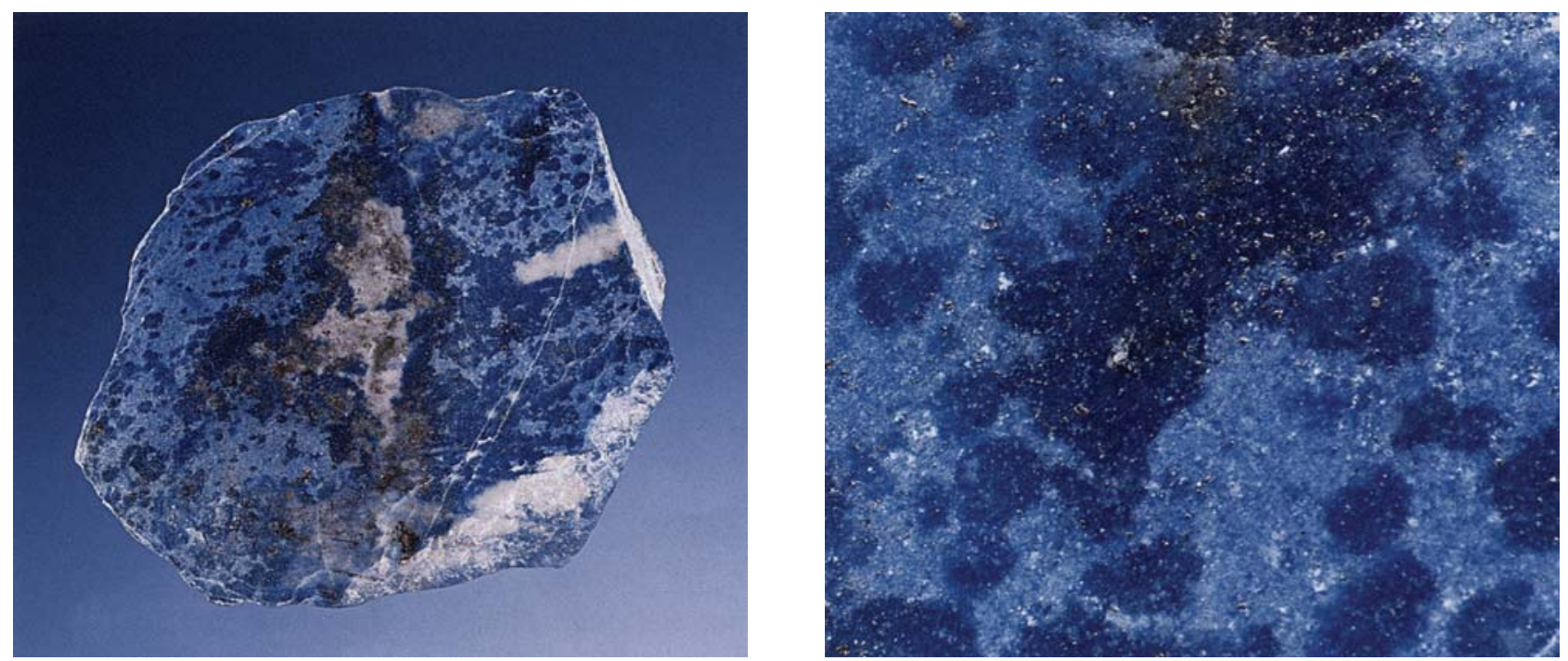

Figure 13. The overall darkness or lightness of blue depends on the number of lazurite grains per given area of the white wollastonite matrix, as shown in this sample (left, $4 \times 5 \mathrm{~cm}$; photo by Maha Tannous). The less lazurite there is, the lighter the overall appearance of the lapis lazuli will be (right; photomicrograph by John I. Koivula, magnified $20 \times$ ).

to dark blue (Munsell tone $=2$ to 6), typically within a narrow hue range of violetish blue (Munsell hue $=5 \mathrm{~PB}$ to $6 \mathrm{~PB})$; some also showed greenish blue. The Afghan samples, as well as the lapis imitations and the sodalite, were visibly more violet in hue (7.5PB to $8.5 \mathrm{~PB})$.

Even small samples of Chilean lapis lazuli showed slightly different tones of blue within a single piece (see, e.g., figure 13 left). When these pieces were examined with magnification (figure 13 right), it was evident that the apparent darkness or lightness of blue depended on the amount of white or colorless minerals (particularly wollastonite) mixed with the lazurite, rather than on the hue of the lazurite itself. Those areas that contained fewer grains of light-colored minerals appeared a darker blue.

Pyrite inclusions in the Chilean material occurred in many different sizes, shapes, and forms. Most commonly, the grains were rounded or displayed highly irregular or "stretched" shapes (figure 14). In the lower-grade polished slabs, the pyrite showed a patchy distribution, often forming irregular bands and aggregates.

Exposure of the Chilean samples to UV radiation confirmed their heterogeneous nature. The lazurite was inert to UV, while the accompanying fluorescent minerals stood out as spots, patches, and veins that fluoresced strong blue-white to short-wave UV, with different areas or veins showing strong orangeyellow to long-wave UV. On the basis of Cuitiño
(1986) and our observations with magnification, these fluorescent minerals are most likely wollastonite, calcite, and haüyne.

S.G. and R.I. are not always useful for identifying lapis lazuli, since it is an aggregate of different minerals. Measurements of 46 Chilean samples (4 to 22 $\mathrm{g}$ ) of varying quality yielded a mean S.G. value of 2.77 , with a standard deviation of \pm 0.06 . This is greater than the reported value for lazurite (2.38-2.45), but it falls within the range reported for commercial grades of lapis lazuli (2.7-2.9; Arem, 1977; Webster, 1994). A spot R.I. of about 1.50 was obtained from the cabochons. This is consistent with the reported R.I. values for lazurite (1.500-1.522), and it is identical to the R.I. for lapis lazuli reported by Webster (1994).

X-ray diffraction analysis identified lazurite and wollastonite as the principal minerals in samples of first-grade lapis lazuli from both Chile and Afghanistan. Additional peaks for plagioclase and calcite were observed in the scans of the Afghan material. These mineral assemblages are consistent with previous investigations, except that wollastonite was not documented in Afghan lapis lazuli by Wyart et al. (1981).

\section{SEPARATION FROM SODALITE, LAPIS SIMULANTS, AND AFGHAN LAPIS LAZULI}

Lazurite vs. Sodalite. Lazurite is easy to distinguish from sodalite (see Box A) by its higher refractive index (1.500-1.522, compared to 1.483-1.487) and 
its higher specific gravity $(2.38-2.45$, compared to 2.14-2.30). Most massive lazurite contains at least traces of pyrite, which further increases its apparent specific gravity relative to sodalite. The presence of brassy specks of pyrite, however, is not diagnostic, as pyrite has also been reported in sodalite (Webster, 1994). Lazurite is inert to UV radiation, whereas sodalite may show an intense orange to orange-red fluorescence to both short- and long-wave UV. Lazurite is also distinguishable by its bright blue streak (compared to the white or pale blue streak of sodalite), and the liberation of hydrogen sulfide gas (with its distinctive rotten egg odor) when hydrochloric acid is applied, or when it is worked on grinding and polishing laps.

Chilean Lapis Lazuli vs. Simulants. Magnification is the most useful tool for this separation. At 10x-45x magnification, the blue color of the natural material was nonhomogeneous, whereas the simulants studied all showed a homogeneous bright, saturated blue coloration that was more purple than the Chilean material. The different minerals in Chilean lapis lazuli were clearly visible as intricate spots, patches, and veinlets, both in daylight and with UV radiation. In particular, the rounded or highly irregular forms displayed by the pyrite inclusions in Chilean lapis lazuli were usually distinct from the equant, straight-edged brassy inclusions commonly seen in the lapis lazuli imitations.

A number of materials have been used as lapis lazuli simulants. As described in Webster (1994) and supplemented by our tests on three samples, these may be distinguished from natural lapis lazuliregardless of the locality of origin-as follows:

1. Gilson-created lapis shows a stronger reaction to hydrochloric acid $(\mathrm{HCl})$ and is more porous (and thus shows a marked increase in weight after immersion in water). Crushed pyrite grains, if added, are very regular in shape and size, and tend to pluck out during polishing. This simulant is considerably lower in hardness (about 3 on the Mohs scale, compared to 5.5 for lapis lazuli) and S.G. (average 2.35).

2. "Swiss/German lapis" (i.e., dyed jasper) appears red with the Chelsea filter (as compared to no reaction for the natural samples), has a higher R.I. (1.54), displays an inferior blue color, does not contain pyrite or react with $\mathrm{HCl}$, and will stain a swab moistened with acetone (as will dyed natural lapis lazuli).

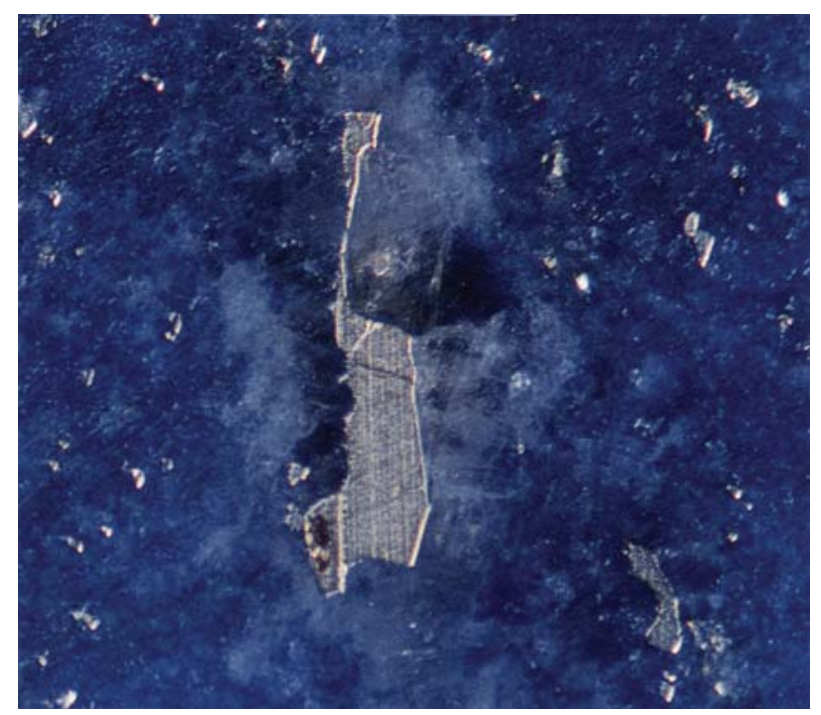

Figure 14. Pyrite exhibits many forms in Chilean lapis lazuli. In addition to the disseminated, fine-grained pyrite with rounded edges, this sample shows pyrite with highly irregular "stretched" shapes. Photomicrograph by John I. Koivula; magnified $40 \infty$.

3. Sintered cobalt-colored blue synthetic spinel has significantly higher values for S.G. (3.52) and R.I. (1.725), appears red with the Chelsea filter, displays cobalt lines in its absorption spectrum, and does not react to $\mathrm{HCl}$. Specks of gold are often added to simulate pyrite.

4. Barium sulfate imitation lapis has a lower S.G. (2.33 measured on the sample we tested), is semitranslucent to strong light, and is indented by the thermal reaction tester, producing a whitish discoloration and a weak acrid odor (see also Koivula and Kammerling, 1991). Although it typically contains crushed pyrite in realistic-looking "veins," the grains are usually very regular in shape and size.

5. Plastic is very soft (a Mohs hardness of 1.5-3), has a lower S.G. (2.47 measured on the sample we tested, which contained pyrite), may be more porous, and indents when tested with the thermal reaction tester (emitting an acrid odor).

Chilean vs. Afghan Lapis Lazuli. None of the Chilean samples studied had the prized "azure" or "ultramarine" hue of the high-quality Afghan material we examined. Our findings are consistent with earlier observations that Chilean lapis lazuli is more spotted (Schumann, 1997) or less pure (Webster, 1994) than Afghan material. Webster (1994) reported that Chilean lapis lazuli, when viewed with UV 
Figure 15. Attractive jewelry is manufactured in Chile using higher-quality lapis lazuli. The bracelet and earrings shown here feature Chilean lapis lazuli and Chilean malachite. Photo by Robert Weldon.

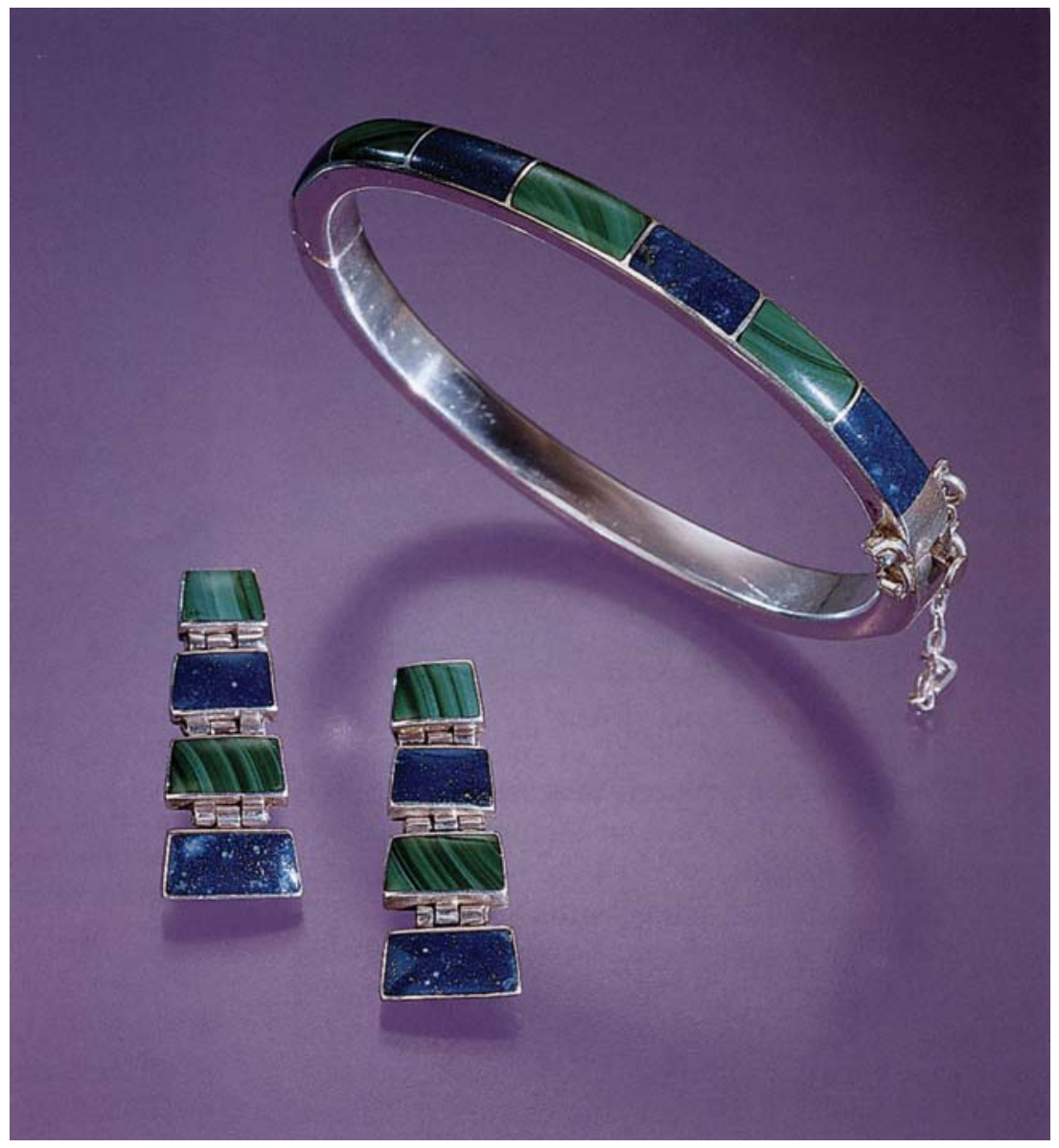

radiation, shows more pronounced spots and streaks of orange or "copper"-colored fluorescence than the Afghan material. Our observations indicate that these fluorescent patches are nearly ubiquitous in Chilean lapis lazuli, and correspond to areas of wollastonite, calcite, and haüyne.

\section{SUMMARY AND CONCLUSION}

Since the deposits were first discovered in the mid19th century, hundreds of tonnes of lapis lazuli have been mined from the Coquimbo Region in the Chilean Cordillera. Field mapping and drilling projects indicate that substantial reserves of lapis lazuli are still present in the traditional mining area. Two companies-Las Flores de Los Andes S.A. and Compañía Minera LapisChile S.A.-are currently mining the lapis lazuli and supplying raw and finished material to local and international markets. Higher-quality lapis lazuli is used for jewelry (figure 15) or for carvings; lower-quality material is carved or used in various ornamental building materials.

Chilean lapis lazuli consists mainly of lazurite, wollastonite, and calcite. It can be readily distinguished from similar-appearing rocks and manufactured imitations by standard gemological techniques.

Acknowledgments: The authors thank Ramon Vega E., Coquimbo, Chile, for providing samples of lapis lazuli and for access to the Las Flores de Los Andes processing plant in La Serena. The authors are also indebted to Wellington Vega A. of Taller Keop's, Ovalle, Chile, and his staff-Teresa Vega A., Elsa Vega A., and Pamela Eriza V. - for their hospitality and assistance during the field visit, as well as to Paola Yéñez R., Maudy Tabilo M., and Amy Melling of the La Serena Information Center. Invaluable assistance with samples and XRD analyses was provided by Ross Pogson and David Colchester of the Australian Museum, Sydney. Updated information on mining techniques and marketing strategies was provided by Jorge Correa, general manager of Las Flores de Los Andes S.A., Jorge Muxi Balsells, managing director of LapisChile S.A., Bernadita Lepe, a manager at LapisChile S.A., and Dr. Sergio Rivano G. of the University of Chile, a consulting geologist to LapisChile S.A. 


\section{REFERENCES}

Anthony J.W., Bideaux R.A., Bladh K.W., Nichols M.C. (1995) Handbook of Mineralogy-Vol. 2: Silica, Silicates; Part 2. Mineral Data Publishing, Tucson, AZ.

Arem J.E. (1987) Color Encyclopedia of Gemstones, 2nd ed. Van Nostrand Reinhold, New York.

Bauer M. (1904) Precious Stones, Their Characters and Occurrence. Charles Griffen and Co., London.

Bowersox G.W., Chamberlin B.E. (1995) Gemstones of Afghanistan. Geoscience Press, Tucson, AZ.

Brendler W. (1934) Sodalite from Bolivia. American Mineralogist, Vol. 19, pp. 28-31.

Burnham S.M. (1886) Precious Stones in Native Art and Literature. Bradlee Whidden, Boston, MA.

Bruggen J. (1921) Informe geológico sobre el yacimiento de lapislázuli Flor de Los Andes del Señor Santiago M. Merry [Geological report on the Flor de Los Andes lapis lazuli deposit of Mr. Santiago M. Merry]. Unpublished report, Santiago, Chile, $10 \mathrm{pp}$.

Bruggen J. (1926) Segundo informe geológico sobre las minas de lapislázuli de Ovalle [Second geological report on the Ovalle lapis lazuli mines]. Unpublished report, Santiago, Chile, 8 pp.

Canut de Bon C. (1991) Apreciaciones sobre las reservas de lapislázuli de yacimientos chilenos [Reserve estimates for the Chilean lapis lazuli deposits]. Unpublished report for El Servicio Nacional de Geología y Minería, December 9, 1991.

Christopher G.W. (1977) Colorado's blue stone of the ancients. Western and Eastern Treasures, Vol. 11, No. 5, pp. 38-40.

Cuitiño L. (1986) Mineralogía y genesis del yacimiento de lapislázuli, Flor de los Andes, Coquimbo, norte de Chile [Mineralogy and genesis of the Flor de los Andes lapis lazuli deposit, Coquimbo, northern Chile]. Revista Geológica de Chile, Vol. 27, pp. 55-67.

Dana E.S. (1892) The System of Mineralogy, 6th ed. John Wiley \& Sons, New York.

Deer W.A., Howie R.A., Zussman J. (1963) Rock Forming Minerals, Vol. 4, Framework Silicates. Longmans, Green and Co., London, pp. 289-302.

Domeyko I. (1860) Elementos de Mineralogía, 2nd ed. Imprenta del Ferrocarril (Railway Press), Santiago, Chile.

Douglas J.D., Ed. (1980) The Illustrated Bible Dictionary. Intervarsity Press, Sydney.

Field F. (1850a) Análisis de lapislázuli de Elqui [Analysis of lapis lazuli from Elquil. Los Anales de la Universidad de Chile por 1850, p. 386.

Field D.F. (1850b) Mineralojia._Lapis lazuli en Chile. Comunicado en una carta escrita al Secretario de la Facultdad de Ciencias. Chile Universidad Anales, p. 340.

Gaines R.V., Skinner H.C.W., Foord E.E., Mason B., Rosenzweig A. (1997) Dana's New Mineralogy, 8th ed. John Wiley \& Sons, New York, pp. 1623-1628.

Heidel A. (1946) The Gilgamesh Epic and Old Testament Parallels. University of Chicago Press, Chicago and London.

Hinks P. (1975) Nineteenth Century Jewellery. Faber and Faber, London, p. 56.

Hogarth D.D., Griffin W.L. (1978) Lapis lazuli from Baffin Island-a Precambrian meta-evaporite. Lithos, Vol. 11, No. 1, pp. 37-60.

Hogarth D.D., Griffin W.L. (1980) Contact-metamorphic lapis lazuli: The Italian Mountain deposits, Colorado. Canadian
Mineralogist, Vol. 18, Part 1, pp. 59-70.

Ivanov V.G. (1976) The geochemistry of formation of the rocks of the lazurite deposits of the southern Baykal Region. Geochemistry International, Vol. 13, No. 1, pp. 26-31.

Koivula J.I., Kammerling R.C., Eds. (1991) Gem news: Imitation lapis lazuli. Gems « Gemology, Vol. 27, No. 1, p. 54.

Kulke H.H.G. (1976) Metamorphism of evaporitic carbonate rocks (NW Africa and Afghanistan) and the formation of lapis lazuli. Abstracts, International Geological Congress (Sydney, Australia), No. 25, Vol. 1, Section 3B, pp. 131-132.

Rivano S. (1975a) Reconocimiento geológico de las nacientes del río Grande Alta Cordillera de Ovalle, entre los $30^{\circ} 30^{\prime}$ and $31^{\circ} 20^{\prime}$ latitud sur, Provincia de Coquimbo [Reconnaissance geology of the headwaters of the Grande Alta Cordillera de Ovalle River, between latitude $30^{\circ} 30^{\prime} \mathrm{S}$ and $31^{\circ} 20^{\prime} \mathrm{S}$, Coquimbo Province]. Unpublished thesis, Departamento de Geología, Universidad de Chile, Santiago.

Rivano S. (1975b) El lapislazuli de Ovalle (Provincia de Coquimbo, Chile) [The lapis lazuli from Ovalle (Coquimbo Province, Chile)]. 6o Congreso Geológico Argentino, Vol. 3, pp. $165-177$.

Rivano S., Sepúlveda P. (1991) Hoja Illapel. Serie Carta Geológica de Chile, escala 1:250000 [Illapel 1:250,000 Geological Map Sheet, Chile]. SERNAGEOMIN (Servicio Nacional de Geología y Minería de Chile), Santiago, Chile.

Rogers A.F. (1938) Lapis-lazuli from San Bernardino County, California. American Mineralogist, Vol. 23, pp. 111-113.

Schultz P.R. (1981) Colorado lapis lazuli from the Blue Wrinkle Mine in Gunnison County. Lapidary Journal, Vol. 34, No. 11, pp. 2344, 2346.

Schumann W. (1997) Gemstones of the World. Sterling Publishing Co., New York.

Silverman D.P. (1978) 50 Wonders of Tutankhamun. An Artabras Book, Crown Publishers, New York.

Sinkankas J. (1997) Gemstones of North America, Vol. 3. Geoscience Press, Tucson, AZ.

Sofianides A.S., Harlow G.E. (1990) Gems @) Crystals from the American Museum of Natural History. Simon and Schuster, New York.

Sutherland L. (1991) Gemstones of the Southern Continents. Reed Books, Sydney, Australia.

Tiglay J.H. (1982) The Evolution of the Gilgamesh Epic. University of Pennsylvania Press, Philadelphia.

von Rosen L. (1990) Lapis lazuli in archaeological contexts. In P. Astrom, Ed., Studies in Mediterranean Archaeology, Pocketbook 93, Jonsered, Foerlag, Sweden.

Ward F. (1996) Atop the Andes-Mining Chile's mountain-high lapis. Lapidary Journal, Vol. 50, No. 3, pp. 36-40.

Webster R. (1994) Gems, Their Sources, Descriptions and Identification, 5th ed. Rev. by P.G. Read, ButterworthHeinemann, Oxford, England.

Wyart J., Bariand P., Filippi J. (1981) Lapis-lazuli from Sar-e-Sang, Badakhshan, Afghanistan. Gems ↔ Gemology, Vol. 17, No. 4, pp. 184-190.

Zeballos J. (1973) Estudio geológico preliminar del yacimiento de lapislázuli de Río Tascadero, Ovalle [Preliminary geological study of the Tascadero River lapis lazuli deposit, Ovalle]. Unpublished report for Empresa National de Mineria, ENAMI, Santiago, Chile, $41 \mathrm{pp}$. 